\title{
Geographic determinants of spatial patterns of Quercus robur forest stands in Latvia: biophysical conditions and past management
}

\author{
Zigmārs Rendenieks ${ }^{(1)}$, \\ Guntis Brūmelis (2), \\ Olǵgerts Nikodemus ${ }^{(1)}$, \\ Didzis Elferts ${ }^{(2)}$
}

\begin{abstract}
Most of the forest area dominated by pedunculate oak (Quercus robur L.) in Latvia was lost to arable land several centuries ago and the remnant patches of $Q$. robur stands are small and spatially scattered. We hypothesized that a large part of the present $Q$. robur stands in the Eastern Baltic area of the hemiboreal forest zone developed around the past manor houses in the period of social and political turmoil and subsequent agricultural land abandonment. Our aim was to determine the relationship of $Q$. robur stand occurrence with soil properties, climatic conditions and proximity to past manor houses. Our study area was the entire territory of Latvia $\left(64,589 \mathrm{~km}^{2}\right)$, divided into 16 landscape regions. We used the State Forest Inventory database to filter out all stands dominated by $Q$. robur $(n=3746)$. Spatial aggregation of the stands was tested by multi-distance spatial clustering analysis (Ripley's K method). Mean stand area and Euclidean nearest-neighbour distance for stands were calculated for landscape regions. Binary logistic regression with the calculation of autocovariates showed that winter temperature, soil texture, carbonate concentration and distance to closest manor house were the independent factors significantly $(p<0.01)$ related to the probability of occurrence of $Q$. robur stands. The results showed that $Q$. robur is spatially clustered, i.e., significantly different from a random distribution $(p<0.05)$. Higher densities of stands occurred in landscape regions with milder maritime climatic conditions. The largest proportional area of stands established between 1885 and 1914 in the period when peasants gained title to lands and manor lords lost control over their land holdings. In addition, in the landscape regions of Rietumkursa, Austrumkursa and Rietumzemgale, the abundance of $Q$. robur stands coincided with high densities of past manor houses. Thus, establishment of the $Q$. robur stands likely responded to suitable conditions (open canopy) made available for tree colonization during the land reform occurred 100 years ago. Our results suggest that priority for conservation should be given to spatial aggregations of stands with high connectivity and on richer soils in more maritime conditions.
\end{abstract}

Keywords: Forest Management, Geographic Distribution, Land Use History, Soil, Manor, Spatial Pattern, Quercus robur

\section{Introduction}

The impact of man on transformation of the landscape has been profound and understanding of these changes is required for the development of optimized management systems (Costanza et al. 2007). Clearing of forest for the exploitation of wood resources together with the conversion of land use to agriculture in the Holocene has been estimated to have reached $60-100 \%$ in most parts of Europe by 1800 AD (Kaplan et al. 2009). Presently, in the European Union, $40 \%$ of woodlands are located in agricultural landscape matrix and $15 \%$ of woodlands are strongly fragmented (Estreguil et al. 2013). In Western Europe, the
(1) University of Latvia, Faculty of Geography and Earth Sciences, Jelgavas iela 1, Riga, LV-1004 (Latvia); (2) University of Latvia, Faculty of Biology, Jelgavas iela 1, Riga, LV-1004 (Latvia)

\section{@ Zigmars Rendenieks (zigmars.rendenieks@lu.lv)}

Received: Oct 21, 2018 - Accepted: Apr 10, 2019

Citation: Rendenieks Z, Brumelis G, Nikodemus O, Elferts D (2019). Geographic determinants of spatial patterns of Quercus robur forest stands in Latvia: biophysical conditions and past management. iForest 12: 349-356. - doi: 10.3832/ifor2979-012 [online 2019-07-05]

Communicated by: Chris Eastaugh existing temperate woodland is mostly represented by secondary forests that regenerated on abandoned agricultural land, and virtually all stands have been managed (Hermy \& Verheyen 2007). In the boreal forest zone of Northern Europe the forest area is less fragmented and woodlands cover $53.2 \%$ of the land area (Forest Europe 2015).

The hemiboreal zone represents the transition between temperate nemoral forests and northern boreal forest, where nemoral species like pedunculate oak Quercus robur L. are close to their northern range limit (Hytteborn et al. 2005). Q. robur is an ecologically plastic species, which behaves as a pioneer species in certain conditions (Eaton et al. 2016). Q. robur exhibits preference for a maritime climate (Krampis 2011, Matisons et al. 2013). Spring, summer and winter temperature, and summer drought are climatic factors known to limit for Q. robur survival and growth in the hemiboreal zone (Drobyshev et al. 2008, Matisons et al. 
2012, Eaton et al. 2016). Since 1900, there has been a shift in the main limiting factors in the Eastern Baltic region from winter temperature to summer temperature (Matisons et al. 2012). Q. robur is mostly found on fertile and moist soils (Neophytou et al. 2010), although it can also regenerate and develop successfully on poorer soils if light conditions are suitable (Ikauniece et al. 2013, Brumelis et al. 2017). In Europe Q. robur rarely forms pure stands and occurs mostly in admixture with other noble broadleaved trees like Carpinus betulus, Fraxinus excelsior, Tilia cordata and Acer platanoides (Eaton et al. 2016). Q. robur also occurs as individual trees in open landscapes and in small patches surrounded by cultivated lands.

Q. robur forests reached maximum extent during the Middle Holocene (Holocene climatic optimum) about 8000-4000 yrs BP (Stivrins et al. 2014) when the climate was more maritime with warmer temperatures and more precipitation (Giesecke 2005). Its range later shrank due to cooling of the climate. In addition to climatic changes, anthropogenic pressure caused wide-scale land-use changes and, consequently, the decrease of $Q$. robur in north-eastern Europe, due to clearing for valuable timber and the expansion of cultivated lands. The most fertile lands were preferred for farming, grazing and timber production. The ship building industry in Latvia during the $17^{\text {th }}$ and $18^{\text {th }}$ centuries created a high demand for Q. robur timber, thus contributing to the loss of previously abundant Q. robur forests (Zunde 1999) and fragmentation of surviving stands. At the beginning of the $20^{\text {th }}$ century, the total forest area in Latvia had fallen to $23.9 \%$ (Vasilevskis 2007), but subsequently increased to $52 \%$ in 2016 . Due to past management decisions, spruce was planted extensively on forested land (Terauds et al.
2011), although soil conditions permitted the growth of Q. robur woodland (Ikauniece et al. 2013). The present area of $Q$. robur as the dominant species is $0.3 \%$ of the total forest area (State Forest Service 2017). In regions of intensively managed agricultural landscape, only about $0.4 \%$ of the forest area on rich soils has been continuously forested for at least 250 years (Fescenko et al. 2014).

In Europe much of the past forested area was open woodland with veteran trees, a landscape that was rapidly lost due to intensive agriculture and forest management (Miklin \& Cizek 2014). In the hemiboreal zone, traditional open woodland parks were centered around manor houses, with cropland in the surrounding area (Lohmus et al. 2014). The feudal manorial system of land ownership existed for centuries across Europe. Manors functioned as agricultural enterprises, in which lands were owned by a titled landowner and were cultivated by peasants (serfs). These areas can be considered as patches of historical agricultural matrix. Aside from administrative and production functions, manors and their surrounding landscapes had significant aesthetic function, reflecting the owner's wealth, status and prevailing architectural styles. The first manorial estates in rural landscapes in Latvia emerged during the $16^{\text {th }}$ century (Nikodemus et al. 2018) and nearly all land belonged to GermanBaltic nobility. In parts of Latvia, peasants were given title to land already around 1850. About one-fifth of the manor houses were burned during an uprising in 1905 (Svabe 1958). However, the manorial estate system was fully dismantled only with the land reform of 1920 when approximately one half of the cultivated land of former manors was given to landless peasants ( $\mathrm{Ni}$ kodemus et al. 2018). In Russia, the manorial system was dismantled around the same time (Nafziger 2012). Even if manor houses were completely destroyed, parks and gardens remained in a part of these areas. Bearing also in mind the need for open areas for establishment of $Q$. robur, we hypothesized that a large part of the present Q. robur stands in the Eastern Baltic area of the hemiboreal forest zone developed around the past manor houses in the period of social and political turmoil and subsequent agricultural land abandonment.

Small and spatially scattered patches of Q. robur stands present a challenge for effective management and conservation activities, particularly as climatic conditions in the future are predicted to promote expansion of the distribution of broad-leaved tree species (Hanewinkel et al. 2013). Our goal was to test the effect of soil properties, climatic conditions and location of past manor houses as spatial determinants for $Q$. robur stand occurrence in Latvia. Our main objectives were: (1) to determine the age group distribution of Q. robur stands; (2) to describe the spatial configuration of Q. robur stands in landscape regions of Latvia; and (3) to determine the main factors explaining $Q$. robur stand occurrence in landscape regions of Latvia. We hypothesized that proximity of past manor houses interacting with climatic and soil characteristics were statistically significant factors explaining the occurrence of these stands. We also determined the protection status of these stands, to assess the need for further conservation measures.

\section{Materials and methods}

\section{Study area}

The study area covered the entire territory of Latvia $\left(64,589 \mathrm{~km}^{2}\right)$. Latvia is located on the Eastern coast of the Baltic Sea, bordering Estonia, Russia, Belarus and Lithuania (Fig. 1). The terrain consists of

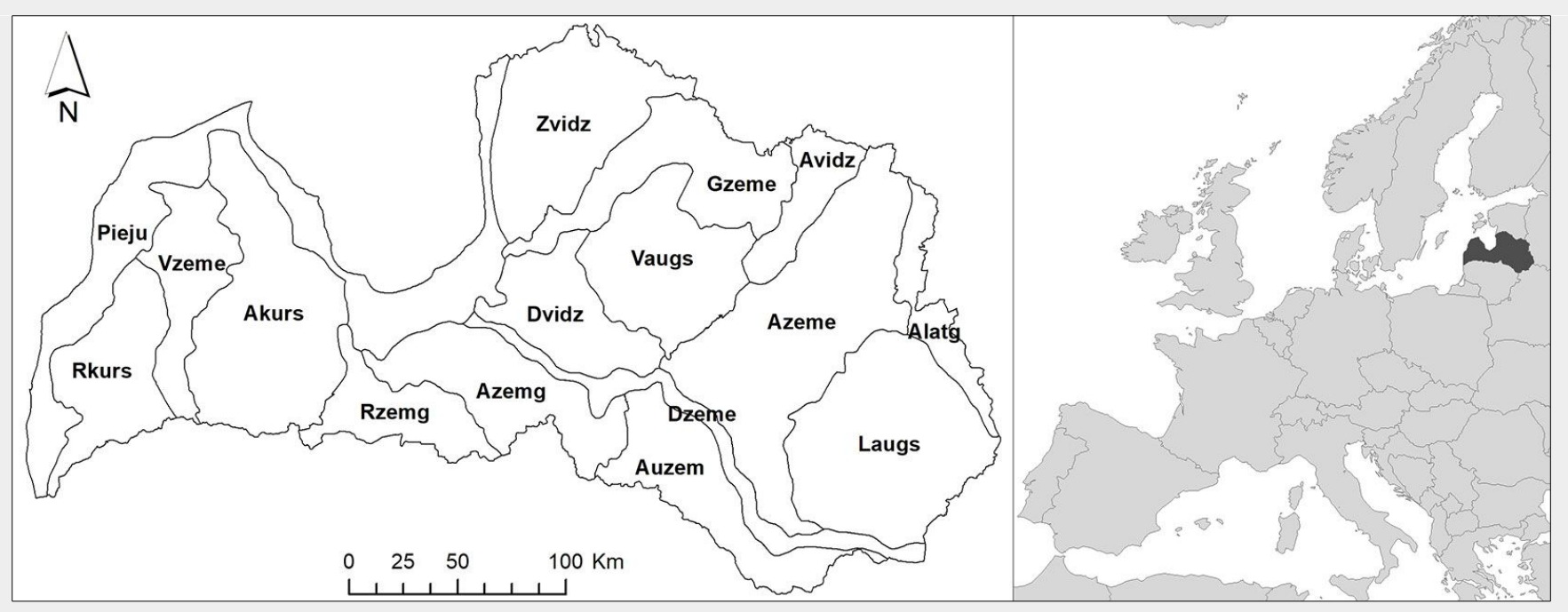

Fig. 1 - Location of study area and boundaries of 16 landscape regions (after Ramans 1994) in Latvia: Piejura (Pieju), Rietumkursa (Rkurs), Ventaszeme (Vzeme), Austrumkursa (Akurs), Rietumzemgale (Rzemg), Austrumzemgale (Azemg), Augšzeme (Auzem), Daugavzeme (Dzeme), Dienvidvidzeme (Dvidz), Vidzeme upland (Vaugs), Gaujaszeme (Gzeme), Ziemelvidzeme (Zvidz), Austrumvidzeme (Avidz), Aiviekstes zeme (Aizem), Austrumlatgale (Alatg) and Latgale upland (Laugs). 
mostly flat lowlands separated by glacial upland regions with low hills (150-300 m a.s.l.). The climate in Latvia is temperate, with mild winters (mean temperature in January is $-5{ }^{\circ} \mathrm{C}$ ) and warm summers (mean July temperature is $+16^{\circ} \mathrm{C}$ ). Annual precipitation reaches $600-760 \mathrm{~mm}$. The climate shifts from maritime influence in the Western part to continental in the Eastern part (Draveniece 2007). Soils in Latvia are formed mostly on glacial sediments (clay, loam, loamy sand or sand), which are covered by aeolian, marine, alluvial or peat sediments (Zelčs et al. 2011). The most common soil taxonomy groups in Latvia are Luvisols, Retisols, Arenosols, Podzols, Gleysols, Phaeozems and Stagnosols (Nikodemus et al. 2018).

Latvia is part of the hemiboreal region where southern boreal coniferous forests merge with Central European nemoral forests (Sjörs 1963). Forest covers 52\% of the land area. The dominant tree species in Latvia are Scots pine (Pinus sylvestris), Silver and Downy birch (Betula pendula and Betula pubescens), and Norway spruce (Picea abies), which together account for $82.8 \%$ of the total forested area. Stands dominated by Q. robur comprise only $0.3 \%$ of the total forested area (State Forest Service 2017).

\section{Spatial datasets}

To analyze the regional occurrence of $Q$. robur stands, we used the landscape classification scheme of Ramans (1994) as the basis for defining 16 landscape regions in Latvia. This classification articulates regional differences, based mostly on major geographic features (large-scale landforms like uplands, lowlands, major river valleys and general landscape features like woodland, bog or lake areas). The proportion of forest cover in landscape regions varied greatly, from $14 \%$ in Rietumzemgale to $63 \%$ in Ventaszeme (Tab. 1).

The Latvian State Forest Register (SFR) geodatabase maintained by the State Forest Service was used as the primary data source of information on Q. robur stands. The database is a compilation of data at the stand-level from mensuration surveys. Each management unit contains information on tree species composition, timber volume, stand density, and stand age. This database contains both a tabular component (numeric and textual characterization) and a geometric component (spatial layer with boundaries of stands). In Latvia, the majority of forest stands are small $(<2$ ha). This data is used in forest management planning and overseeing forest management, including issuing logging permits. We used climatic maps from the Latvian Centre of Meteorology, Geology and Environment to derive values of mean February temperature as one of limiting factors for survival of Q. robur in Latvia (Matisons et al. 2012). Due to the lack of reliable and detailed soil maps in Latvia, we used the Map of Quaternary deposits map of Latvia at

Tab. 1 - Descriptive statistics of Q. robur stands in landscape regions of Latvia. (*): the proportion of Q. robur is shown as percentage of total forested area in each landscape region.

\begin{tabular}{lccccc}
\hline Landscape region & $\begin{array}{c}\text { Area } \\
\text { (ha) }\end{array}$ & $\begin{array}{c}\text { Forest } \\
\text { cover (\%) }\end{array}$ & $\begin{array}{c}\text { Q. robur } \\
\text { area (ha) }\end{array}$ & $\begin{array}{c}\text { Q. robur } \\
\text { proportion } \\
\text { (\%) }\end{array}$ & $\begin{array}{c}\text { No. of manor } \\
\text { houses } \\
\text { per 100 } \mathbf{k m}^{2}\end{array}$ \\
\hline Aiviekstes zeme & 824,361 & 45 & 180.41 & 0.05 & 1.25 \\
Augszeme & 339,565 & 45 & 71.02 & 0.05 & 2.94 \\
Austrumkursa & 644,634 & 41 & 498.63 & 0.19 & 4.37 \\
Austrumlatgale & 147,116 & 41 & 14.75 & 0.03 & 1.56 \\
Austrumvidzeme & 152,964 & 44 & 22.82 & 0.04 & 2.81 \\
Austrumzemgale & 374,319 & 58 & 95.46 & 0.05 & 3.02 \\
Daugavzeme & 189,823 & 39 & 90.53 & 0.14 & 3.53 \\
Dienvidvidzeme & 289,962 & 50 & 103.32 & 0.08 & 2.45 \\
Gaujaszeme & 390,907 & 56 & 166.02 & 0.08 & 2.43 \\
Latgale upland & 659,105 & 34 & 96.97 & 0.05 & 3.38 \\
Piejura & 716,684 & 60 & 125.70 & 0.03 & 2.13 \\
Rietumkursa & 328,104 & 36 & 1030.87 & 0.94 & 6.25 \\
Rietumzemgale & 223,130 & 14 & 111.88 & 0.40 & 7.66 \\
Ventaszeme & 255,257 & 63 & 145.00 & 0.09 & 2.90 \\
Vidzeme upland & 419,786 & 52 & 156.63 & 0.08 & 2.81 \\
Ziemelvidzeme & 504,487 & 45 & 302.90 & 0.13 & 2.83 \\
\hline
\end{tabular}

scale of 1:200.000 (Latvijas Kvartara Nogulumu Karte 1981) as a proxy for characterization of soils. The results from geochemical mapping of Latvia at scale of 1:500.000 (Latvijas Geokimiska Karte 2001) provided information on concentrations of carbonates and texture classes of soil parent material (clay, silt, loam, loamy sand, sand, unsorted material, peat) and bedrock (dolomite, gypsite, limestone). Locations (as points) of all 1984 historical manor houses were derived from a map published by Potapova (1977); this map included all types of feudal rural administrative centers.

Information on protected areas (PA) was obtained from the Nature Conservation Agency (DAP) geoportal OZOLS (http:// ozols.daba.gov.lv/pub/). This dataset includes all types of terrestrial protected areas in Latvia, i.e., Biosphere Reserves, National Parks, Strict Nature Reserves, Nature Reserves, Nature Parks, Protected Landscape Areas, Microreserves and Natura 2000 sites. Accessory data sources included the "GIS Latvia" cartographic dataset (Envirotech 2015).

\section{Analysis steps}

At the data processing stage, we extracted forest stands from the SFR database using criteria of tree species composition and area. Since Q. robur rarely forms pure stands, we used a compositional threshold of $\geq 70 \%$ (as the dominant species) of stand timber volume to select stands that were dominated by $Q$. robur. Only stands with area $>0.1$ ha were considered, excluding sub-stand patches like those formed of large legacy trees. In total 3746 Q. robur-dominated forest stands with total area of 3272.2 ha were selected for this study. Data selection and process- ing were done with ArcMap $^{\circledR}$ ver. 10.3 (ESRI, Redlands, CA, USA) using selection queries in attribute tables and data subsetting. The selected stands were split by landscape regions and converted into raster thematic maps. These maps were analyzed with Fragstats ver. 4.2 (McGarigal et al. 2012) to calculate landscape pattern metrics, i.e., quantitative parameters describing the composition and spatial configuration of Q. robur stands. We used the metrics Patch Area (AREA) and Euclidean Nearest-Neighbor Distance (ENN) at the patch level. For the calculation, we prepared thematic raster maps with cell size $10 \times 10 \mathrm{~m}$, showing all Q. robur stands divided among landscape regions. The eightcell neighborhood rule was used to determine spatial relationships.

To detect aggregation patterns, multi-distance spatial clustering of Q. robur stands was analyzed with the Ripley's $\mathrm{K}$ function in ArcMap 10.3 using 99 permutations at 50 distance bands of $500 \mathrm{~m}$. For this, polygons of $Q$. robur stands were converted to points using polygon centroids. Separately, Q. robur stand proximity to past manor houses was assessed using the "Buffer" function in ArcMap 10.3 with distance threshold of $3 \mathrm{~km}$.

To determine whether the probability of occurrence of a $Q$. robur stand at a particular point was related to distance from a manor house, and climatic and soil texture factors, an autologistic binary regression model as implemented in software $R$ ver. 3.5.0 (R Core Team 2018) was used. For reference we generated 3746 randomly placed points (to match the number of observed $Q$. robur stands), covering the entire area of Latvia and calculated the same factor values as for the observed Q. robur points. To account for spatial autocorrela- 


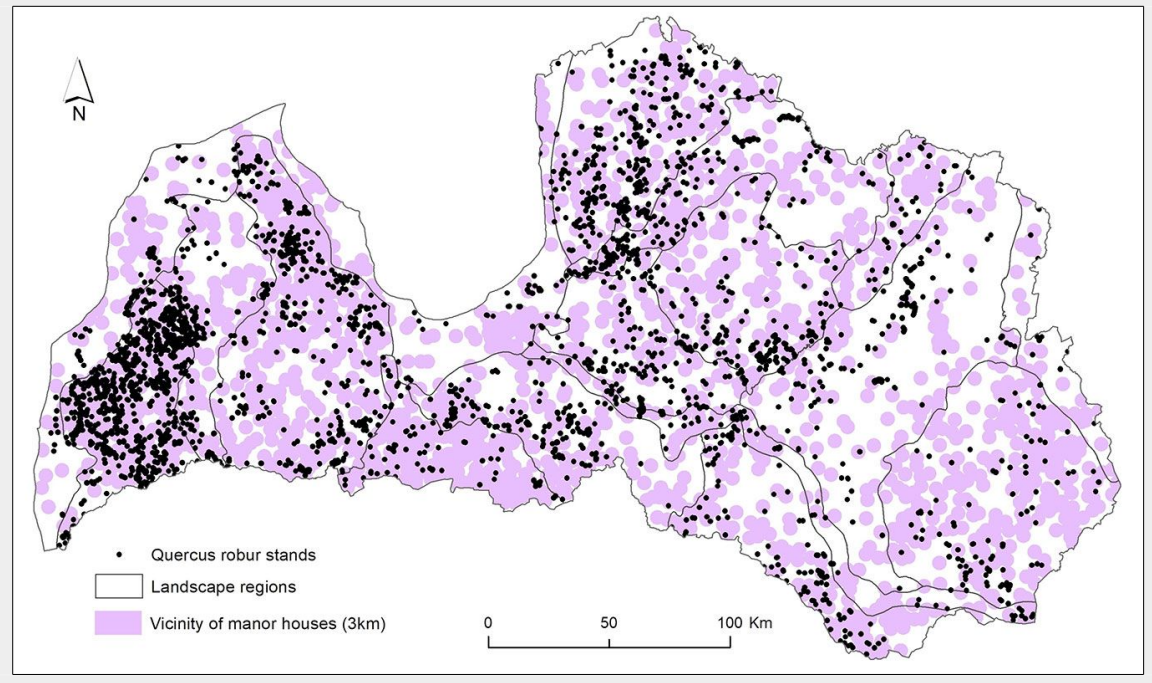

Fig. 2 - Location of Quercus robur stands and the vicinity (up to $3 \mathrm{~km}$ distance) to past manor houses.

tion, a distance-weighted autocovariate (distance used was $1000 \mathrm{~m}$ ) was included using the R package "spdep". Independent variables in the model were distance to nearest manor house (MANDIST), mean February temperature (TEMP) as the main limiting climatic factor in the past, texture type (FRACT) and concentration of carbonates in topsoil (CACONC). We used a confidence level of 0.95 . The R package "emmeans" was used to perform a post-hoc test (pairwise comparisons) of occurrence probabilities between FRACT levels. Pvalue adjustment was done with Tukey's method for comparing a family of 8 estimates.

\section{Results}

Despite the large variation observed across the country, the cover of Q. robur stands was very low in all landscape regions - below $1 \%$ of the total forested area.
Fig. 3 - Statistical distributions of pattern metrics for Quercus robur stands in landscape regions of Latvia. Patch area (top) and Euclidean NN distance (bottom). Outliers are not shown.
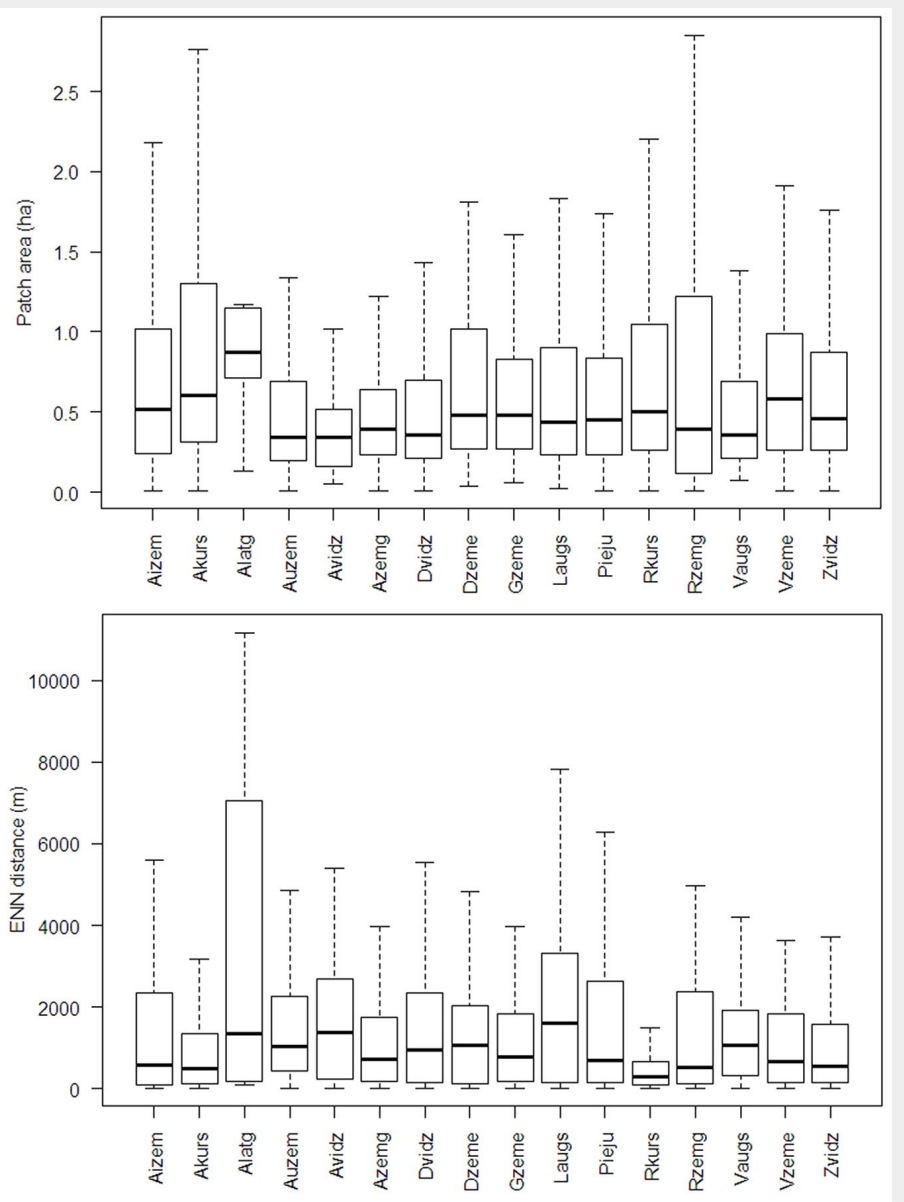

Q. robur stands comprised only $0.03-0.94 \%$ of the forested area in the landscape regions (Tab. 1). Two landscape regions contained almost half of all Q. robur stands of Latvia and half of the landscape regions together contained only $19.5 \%$ of the total Q. robur area. The highest total area (1030 ha) of $\mathrm{Q}$. robur stands was recorded in the $\mathrm{Ri}$ etumkursa (Rietumkursa upland) landscape region, twice more than that in the landscape region with the next highest area, Austrumkursa (Austrumkursa upland $-498 \mathrm{ha}$ ).

The number of manor houses also differed among landscape regions (1.25-7.66 per $100 \mathrm{~km}^{2}$ ). From five landscape regions (Rietumzemgale, Rietumkursa, Austrumkursa, Daugavzeme and Latgale upland) with the highest densities of manor houses, four of these also had the highest proportion of Q. robur stand area. Proportion of area of $Q$. robur stands showed strong positive correlation with the number of manor houses per $100 \mathrm{~km}^{2}$ in landscape regions $(r=0.72, p<0.05)$.

\section{Geographic pattern of Q. robur stands}

Multi-distance spatial analysis (Ripley's K) showed that $Q$. robur stands exhibited a significant spatial clustering (confidence level 99\%) in all distance bands compared to the same number of random points. As expected, Ripley's K analysis also revealed a significant clustering of former manor house locations, but only at distances exceeding $2.5 \mathrm{~km}$.

As shown in Fig. 2, most of the Q. robur stands occur in the vicinity of the past manor houses ( $3 \mathrm{~km}$ distance threshold). The proportion of area of Q. robur stands in landscape regions was strongly correlated $(r=0.76)$ to that of manor houses.

Spatial pattern analysis of Q. robur stands revealed a low median patch area ( $<1 \mathrm{ha})$ in all landscape regions, with maximum area less than 3 ha (Fig. 3). The ENN metric at patch level indicated that the median distance to nearest neighbor patch was less at $1 \mathrm{~km}$ for almost all landscape regions, and lowest for the landscape regions with greater proportional area of Q. robur stands (e.g., Rietumkursa). As expected, the median EEN distance was highest in the eastern landscape regions (Austrumlatgale, Latgale upland, Austrumvidzeme) where the area covered by $Q$. robur stands was lowest. In total, only $19.8 \%$ of stands were isolated at distances greater than 2 $\mathrm{km}$.

\section{Stand age group distribution}

The median age of $Q$. robur stands was 94.8 years. Almost one half (47.3\%) of the Q. robur stands were older than 100 years and those older than 200 years occurred in 11 of 16 landscape regions. The oldest stand was 305 years old, located in the Gauja National Park in the Gaujaszeme landscape region. More than half (52.7\%) of Q. robur stands above the age of 90 years (by area) were under some type of protection (strict 
nature reserve, nature park, microreserve etc.).

Forest age distribution (grouped by decades) showed two periods of notable increase in area of Q. robur stands (Fig. 4). The most recent period corresponds to the establishment in the years 1993-2014, as indicated by the peak of area for stands younger than 20 years. These stands account for 332.8 ha, which is $10.3 \%$ of the total Q. robur stand area. The second peak in the age distribution (stands with age 101130 years) suggests a great increase in establishment of $Q$. robur in the period of 1885-1914 (over 60\% compared to that in 1865-1874). Stands with this age comprise $42 \%$ of all Q. robur stands by area. Among age classes, the proportions of $Q$. robur stands located $<3 \mathrm{~km}$ from manor houses were similar: $69.3 \%, 75.5 \%, 75.8 \%$ and $70.3 \%$ in the age classes 1-30, 31-100, 101-130 and 130 years, respectively.

\section{Predictors of Q. robur patch occurrence}

The binary regression model applied to explain the spatial distribution of Q. robur stands showed that all tested factors had significant independent effect $(p<0.01$ or $\mathrm{p}<0.001$ - Tab. 2). The spatial autocovariate was also significant $(p<0.001)$ in this model, indicating the aggregation of $Q$. robur stands.

Distance to past manor houses (MANDIST) was inversely related to the probability of occurrence of $Q$. robur stands $(p<0.001)$. February mean temperature (TEMP) was also significant $(p<0.001)$ and positively related to $Q$. robur occurrence. We found that carbonate concentration (CACONC), as an indicator for soil richness, was inversely related to the occurrence of $Q$. robur stands (significance $p<0.01$ ). From pairwise comparison of the soil texture types (FRACT), sand and loam significantly differed $(p<0.01)$ as predictors for $Q$. robur occurrence. These two types were the most common soil texture classes for $Q$. robur stands in Latvia (Tab. 3). The proportion of $Q$. robur stands on sand parent material was similar to that predicted by distribution of randomly selected points, while the occurrence on loam was much lower (22.3\% of total stands) than expected (34.5\% of random points). However, Q. robur occurrence on loamy sand was higher than expected $(23.0 \%$ and $10.2 \%$, respectively).

\section{Protection of Q. robur stands}

About half of the older $Q$. robur stands (age >150 years) were under protection, while only $20 \%$ of the area of Q. robur stands that originated in the period of 1885-1914 was under some type of formal protection.

\section{Discussion}

Our results reflect the complex history of Q. robur forests in Latvia by considering factors like climate, soils and historical management to explain the existing spatial

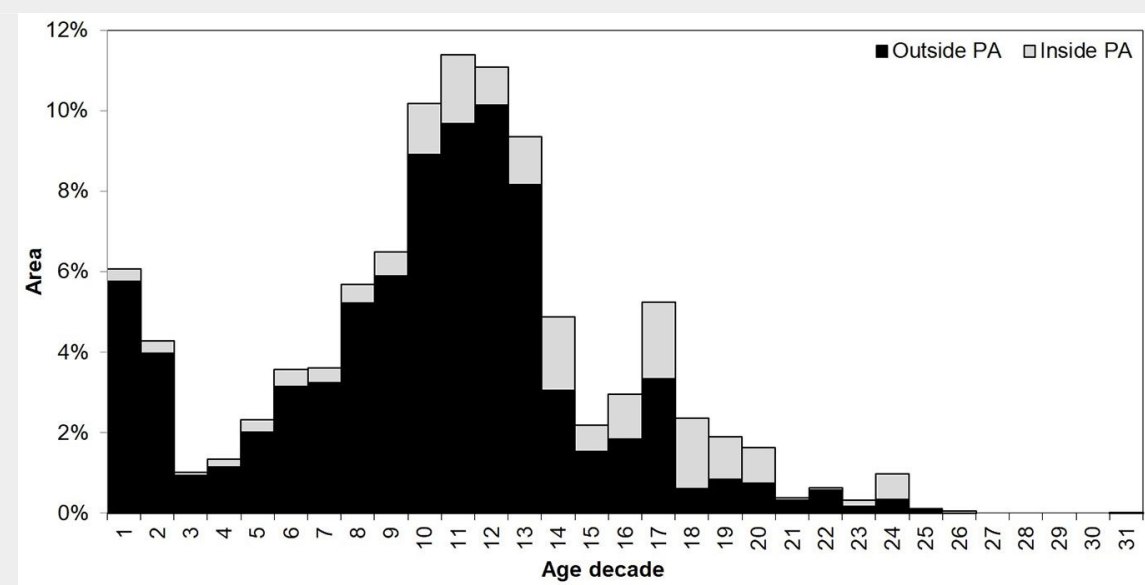

Fig. 4 - Proportional area (\%) of Quercus robur stands in age classes, inside and outside protected areas (PA).

Tab. 2 - Analysis of Deviance Table (Type II test) for Quercus robur stand occurrence in relation to factors of distance to nearest past manor house (MANDIST), mean February temperature (TEMP), type of granular fraction of sediments (FRACT) and concentration of calcium in topsoil (CACONC). The significance of spatial autocovariate is also shown. (df): degrees of freedom.

\begin{tabular}{lrcl}
\hline Factor & \multicolumn{1}{c}{$\chi^{2}$} & df & p-value \\
\hline MANDIST & 51.14 & 1 & $<0.0001$ \\
TEMP & 164.75 & 1 & $<0.0001$ \\
FRACT & 26.87 & 7 & $<0.0001$ \\
CACONC & 9.20 & 1 & $<0.0001$ \\
spatial autocovariate & 2304.30 & 1 & $<0.0001$ \\
\hline
\end{tabular}

Tab. 3 - The distribution of soil texture types of soil parent material for Quercus robur stands and random points in Latvia (by number).

\begin{tabular}{lcc}
\hline Soil texture classes & $\begin{array}{c}\text { Q. robur stands } \\
\text { (\%) }\end{array}$ & $\begin{array}{c}\text { Random points } \\
(\%)\end{array}$ \\
\hline sand & 38.2 & 38.1 \\
loam & 22.3 & 34.5 \\
loamy sand & 23.0 & 10.2 \\
clay & 10.0 & 10.5 \\
silt & 3.5 & 4.3 \\
unsorted material & 2.0 & 1.2 \\
bedrock & 0.4 & 0.4 \\
peat & 0.6 & 0.7 \\
\hline
\end{tabular}

distributions of these stands. The study showed that distance to past manor houses, soil properties and climate were significant independent predictors of the present geographic distribution of $Q$. robur stands in Latvia. The stands were highly spatially aggregated in areas around the past manor houses, which were mainly established in favorable climate and on fertile soils.

\section{Past land management}

Human impact played a major role in the dramatic decrease of broadleaved forests in Latvia during the previous 300 years and influenced the current situation through management legacies (Jõgiste et al. 2018). Despite widespread harvesting of Q. robur timber for ship building in $17^{\text {th }}$ century, significant areas of Q. robur stands were present in Western Latvia during the first half of the $19^{\text {th }}$ century (Zunde 1999). However, in other parts of present-day Latvia, Q. robur stands were rare due to the extensive timber harvesting carried out in previthat since 1663 , Q. robur trees and stands that had remained on agricultural lands were protected in the Dutchy of Courland and Semigallia (as part of Polish-Lithuanian Commonwealth - Strods 1999). This area coincides with the Western and central part of the Russian Empire, forest laws allowed unregulated harvesting in forests of private manor estates, including Q. robur ous centuries. Historical records indicate parts of Latvia. Later, when Latvia was a 


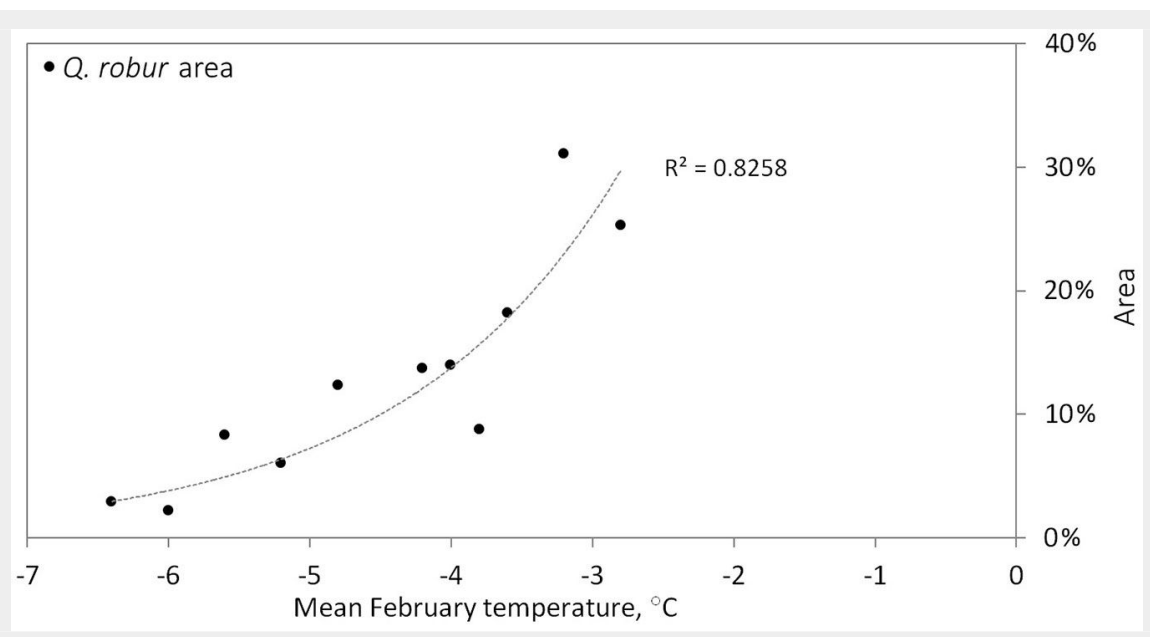

Fig. 5 - The relationship between the proportion of area (\% of forested area) of Quercus robur stands and mean February temperature in Latvia.

stands. In the Western part of Latvia these regulations were stricter, requiring forest regeneration after harvests in forests of manor estates. This was in contrast to Sweden, where at that time, land use in manor estates was much more strictly regulated (Strods 1999). The history of harvest of Q. robur is one of the reasons underlying the current lack of very old stands in Latvia. During this period planting of trees was mostly restricted to gardens and parks of manor estates (Strods 1999). Q. robur is usually the oldest remaining tree found in manor parks, but other deciduous trees such as Tilia cordata and Acer platanoides were also widely planted (Sauliene et al. 2018).

Manor estates firstly were established on fertile land with favorable topography in suitable climate (Potapova 1977), but we found an independent effect of these factors. There was a significant association of location of present day Q. robur stands in all age classes with manor estates. The peak in the age distribution of $Q$. robur stands corresponding to the period of 1885-1914 occurred at a time of widespread social unrest and political change in the Russian Empire. With the social turmoil and military conflicts in the beginning of the $20^{\text {th }}$ century, forests in Latvia were rapidly and widely harvested without replanting. Due to uncertainties of the revolutionary situation, many rulers of manors decided to harvest or sell their forests (Zunde 1999). In 1935 only 1150 ha of Q. robur stands remained in Latvia, including 500 ha in the Vidzeme region, 150 ha in the Zemgale region and 100 ha in the Latgale region (Kiršteins 1936). The peak in age distribution likely reflects a period favorable for Q. robur establishment on previous agricultural land in proximity of the estates, which can also explain the clustered spatial pattern of the stands. At that time, harvest of Q. robur was common in manor estates (Strods 1999). Much of the land further from estates was allotted to peasants starting from early 1850 s (Boruks 2003), when the focus was on agricultural land use and not forestry. Similar vicissitudes also occurred in Estonia (Maandi 2010).

In Latvia stands with age over 150 years comprised 534 ha or $16.6 \%$ of all analyzed Q. robur stands. Nutt et al. (2013) found that in Estonian manor parks around one half of surviving trees (mostly Q. robur due to the long lifespan) were trees originally planted at time of establishment of park and thus are at least 150 years old. Similarly, many of the older stands in stands in Latvia likely formed from historical parks.

The recent peak in the age structure has resulted from the increased planting of $Q$. robur in state forests, as well as the use of silvicultural methods promoting oak establishment and survival in clearcuts. Indeed, since 2000 it has been common practice in Latvian state forests to retain Q. robur trees in clearcuts, even where Q. robur is not the dominant species in the stand. The continuation of this practice, in combination with warming climate, could potentially lead to increased occurrence of $Q$. robur stands in Latvia in the future. Interestingly, the majority of the young stands were also close to former manor houses, i.e., they occur in areas of aggregations of older stands.

\section{Soil}

Since reliable soil maps for forested areas in Latvia are lacking, we used carbonates and texture classes of soil parent material to characterize the substrate of $Q$. robur stands, as the respective survey of these variables had been carried out. The high variation observed in forested area among landscape regions (Tab. 1) is the result of historical slash-and-burn cultivation where the most fertile soils were deforested for agriculture (Zunde 1999), as in other areas of Europe (Wulf et al. 2010). Our results showed that higher carbonate concentrations and the presence of loam parent material are linked to a lower probability of $Q$. robur occurrence. This inverse relationship indirectly confirms the historical destruc- tion of Q. robur forests on soils most suited for cultivation (Fescenko et al. 2014). Also, most of the $Q$. robur stands that have survived to this day grow on sandy parent material (Tab. 3), which also confirms that $Q$. robur is an ecologically plastic species (Ikauniece et al. 2013). However, there was a preference of Q. robur stands for loamy sand, likely as these soils, compared to loams, were not the most preferred for agricultural use. We note that soils with double-layered parent material, where the topsoil contains more sand, are common in Latvia (Nikodemus et al. 2018) and in this study the carbonate concentration (CACON) values and texture type only characterized the topsoil. Data was not available for deeper soil layers.

\section{Climate}

Climatic conditions represent a major factor driving the occurrence of $Q$. robur stands. Sub-oceanic climatic conditions determine the occurrence of $Q$. robur stands in Latvia and also in Europe in general (Schubert \& Vent 1990, Krampis 2011), In Latvia, Q. robur occurrence decreases with increasing distance from the sea (Krampis 2011). The proportion of area of $Q$. robur stands showed strong $\left(r^{2}=0.82, p<0.05\right)$ association with mean February temperature (Fig. 5) as a proxy for climate continentality. The Eastern part of Latvia has a continental climate (shorter vegetation seasons, colder winters) and Western part has mostly maritime climatic influences (longer vegetation seasons and mild winters).

\section{Implications for management}

The role of past management effects and legacies on the establishment of Q. robur stands is understudied and investigations are needed to synthesize perspectives of land use change, cultural and historical studies, landscapes and ecology to explain the complex history and development of these areas. A question remains about the conservation of $Q$. robur stands inside and outside manor parks, as we did not have data on the origin of stands. Today about half of the older Q. robur stands $(>150$ years) are under protection, compared to only $20 \%$ (by area) of those established in the period 1885-1914. Many of the older stands in the areas around manor houses are likely relicts of parks and gardens with cultural and historical significance as well as ecological and landscape values (Sauliene et al. 2018). Although more than half of older stands are under some kind of protection, the old trees will continue to deteriorate and die, resulting in the vanishing of this woodland in its current form (Nutt et al. 2013). This will affect the value of traditional rural landscapes in which manor gardens and parks have been crucial elements for centuries. However, conservation of the stands with age 100-130 years by protection to avoid harvest would prevent a temporal gap in the continuity of ecological and social values of these forests. Fur- 
ther, the recent establishment of young $Q$. robur stands close to historical manor houses is expected to promote the spatial continuity of these stands, thereby reducing their current fragmentation and favoring their biological and conservation values (Lohmus et al. 2014). Q. robur stands in protected and production forests in Latvia will increase their coverage due to policy of retention of young $Q$. robur trees in clearcuts and climate change effects. Conservation of $Q$. robur woodland should focus on the identification of clusters of stands with age 101 years or more (which is the harvesting age threshold in Latvia) that have dispersal connectivity with the typical nemoral vascular plant communities and epiphytes associated with $Q$. robur. Additional protection for older stands with age $>150$ years is crucial.

\section{Conclusions}

The occurrence of $Q$. robur stands analyzed in this study was well explained by substrate, climatic and historical management as independent factors. Proximity to past manor houses was a strong predictor for the occurrence of $Q$. robur stands. In landscape regions Rietumkursa (upland), Austrumkursa (upland) and Rietumzemgale (lowland) where a high number of manorial estates occurred, Q. robur stands cover relatively high proportions of forested areas, due to favorable soil, climatic and scenic conditions. The peak in Q. robur age group distribution indicated successful establishment of the stands around manor estates in a time of social and political turmoil. Management should focus on clusters of stands, particularly when ageing veteran trees have high occurrence, to retain their cultural and ecological value.

\section{Acknowledgements}

This study was partially funded by the $\mathrm{Na}$ tional Research Programme "The value and dynamic of Latvia's ecosystems under changing climate - EVIDEnT". We thank two anonymous reviewers for their valuable comments on the manuscript.

\section{References}

Boruks A (2003). Zeme, zemnieks un zemkopiba Latvija: no senakiem laikiem lidz musdienam [The land, peasant and agriculture in Latvia. From early times till the present day]. Latvijas Lauksaimniecibas Universitate, Jelgava, Latvia, pp. 717. [in Latvian]

Brumelis $G$, Ikauniece $S$, Voiceščuka A, Artistova A, Treimane A, Dauškane I, Elferts D, Tjarve D (2017). Tree regeneration in noble broadleaved tree stands at their northern limit: implications for conservation management. Environmental and Experimental Biology 15: 275-282. - doi: 10.22364/eeb.15.28

Costanza R, Graumlich L, Steffen W, Crumley C, Dearing J, Hibbard K, Leemans R, Redman C, Schimel D (2007). Sustainability or collapse: what can we learn from integrating the history of humans and the rest of nature? AMBIO 36 (7): 522-527. - doi: 10.1579/0044-7447(2007)36
[522:SOCWCW]2.0.CO;2

Draveniece A (2007). Okeaniskas un kontinentalas gaisa masas Latvija [Oceanic and continental air masses over Latvia]. Latvijas Vegetacija 14: 109. [in Latvian]

Drobyshev I, Niklasson M, Eggertsson O, Linderson $\mathrm{H}$, Sonesson K (2008). Influence of annual weather on growth of pedunculate oak in southern Sweden. Annals of Forest Science 65 (5): 1-14. - doi: 10.1051/forest:2008033

Eaton E, Caudullo G, Oliveira S, De Rigo D (2016). Quercus robur and Quercus petraea in Europe: distribution, habitat, usage and threats. In: "European Atlas of Forest Tree Species” (San-Miguel-Ayanz J, De Rigo D, Caudullo G, Houston Durrant T, Mauri A eds). Publication Office of the European Union, Luxembourg, pp. 160-163. doi: $10.2788 / 4251$

Envirotech (2015). GIS Latvija 10.2 database. Riga, Latvia, web site. [online] URL: http:// www.envirotech.Iv/lv/aktualitates/gis-latvija-102/

Estreguil C, Caudullo G, De Rigo D, San Miguel J (2013). Forest landscape in Europe: pattern, fragmentation and connectivity. European Commission Joint Research Centre, Ispra, Italy, pp. 16. [online] URL: http://publications.jrc.ec. europa.eu/repository/bitstream/111111111/27726/1 /lb-na-25717-en-n.pdf

Fescenko A, Nikodemus O, Brumelis G (2014). Past and contemporary changes in forest cover and forest continuity in relation to soils (Southern Latvia). Polish Journal of Ecology 62 (4): 625-638. - doi: 10.3161/104.062.0408

Forest Europe (2015). State of Europe's forests 2015. Ministerial Conference on the Protection of Forests in Europe, Forest Europe Liaison Unit, Madrid, Spain, pp. 314. [online] URL: http://www.foresteurope.org/docs/fullsoef2015 .pdf

Giesecke T (2005). Holocene dynamics of the southern boreal forest in Sweden. The Holocene 15 (6): 858-872. - doi: 10.1191/0959683605 hl859ra

Hanewinkel M, Cullmann DA, Schelhaas MJ, Nabuurs GJ, Zimmermann NE (2013). Climate change may cause severe loss in the economic value of European forest land. Nature Climate Change 3 (3): 203-207. - doi: 10.1038/nclimate 1687

Hermy M, Verheyen K (2007). Legacies of the past in the present-day forest biodiversity: a review of past land-use effects on forest plant species composition and diversity. In: "Sustainability and Diversity of Forest Ecosystems" (Nakashizuka T ed). Springer, Tokyo, Japan, pp. 361-371. - doi: 10.1007/978-4-431-73238-9_1 Hytteborn H, Maslov AA, Nazimova DI, Rysin LP (2005). Boreal forests of Eurasia. In: "Coniferous forests, ecosystems of the world" (Andersson FA ed). Elsevier, Amsterdam, Netherlands, pp. 23-99. [online] URL: http://books.google. com/books?id= YoOoxKYSJAC

Ikauniece S, Brumelis G, Kasparinskis R, Nikodemus O, Straupe I, Zarinš J (2013). Effect of soil and canopy factors on vegetation of Quercus robur woodland in the boreo-nemoral zone: a plant-trait based approach. Forest Ecology and Management 295: 43-50. - doi: 10.1016/j.foreco. 2013.01.019

Jõgiste K, Frelich LE, Laarmann D, Vodde F,
Baders E, Donis J, Jansons A, Kangur A, Korjus H, Köster K, Kusmin J (2018). Imprints of management history on hemiboreal forest ecosystems in the Baltic States. Ecosphere 9 (11): e02503. - doi: 10.1002/ecs2.2503

Kaplan JO, Krumhardt KM, Zimmermann N (2009). The prehistoric and preindustrial deforestation of Europe. Quaternary Science Reviews 28 (27-28): 3016-3034. - doi: 10.1016/j.qua scirev.2009.09.028

Kiršteins K (1936). Ozols (Quercus robur) Kurzeme [Oak (Quercus robur) in Kurzeme]. Mežsaimniecibas Rakstu Krajums (14): 41-81. [in Latvian]

Krampis I (2011). Boreala un nemorala bioma kokaugu sugu regionala izplatiba Latvija [Regional distribution of boreal and nemoral biome woody plants in Latvia]. Doctoral dissertation, University of Latvia, Riga, Latvia, pp. 128. [in Latvian]

Latvijas Geokimiska Karte (2001). Geochemical map of Latvia. Valsts Geologijas Dienests, Riga, Latvia. [in Latvian]

Latvijas Kvartara Nogulumu Karte (1981). Map of Quaternary sediments in Latvia. Latvijas Valsts Geologijas Dienests, Riga, Latvia. [in Latvian] [CD-ROM]

Lohmus K, Paal T, Liira J (2014). Long-term colonization ecology of forest-dwelling species in a fragmented rural landscape-dispersal versus establishment. Ecology and Evolution 4 (15): 31133126. - doi: 10.1002/ece3.1163

Maandi P (2010). Land reforms and territorial integration in post-Tsarist Estonia, 1918-1940. Journal of Historical Geography 36 (4): 441-452. - doi: 10.1016/j.jhg.2010.03.005

Matisons R, Elferts D, Brumelis G (2012). Changes in climatic signals of English oak tree-ring width and cross-section area of earlywood vessels in Latvia during the period 1900-2009. Forest Ecology and Management 279: 34-44. - doi: 10.1016/ j.foreco.2012.05.029

Matisons R, Elferts D, Brumelis G (2013). Pointer years in tree-ring width and earlywood-vessel area time series of Quercus robur. Relation with climate factors near its northern distribution limit. Dendrochronologia 31 (2): 129-139. - doi: 10.1016/j.dendro.2012.10.001

McGarigal K, Cushman SE, Ene E (2012). FRAGSTATS v4: spatial pattern analysis program for categorical and continuous maps. Web site. [online] URL: http://www.umass.edu/landeco/ research/fragstats/fragstats.html

Miklin J, Cizek L (2014). Erasing a European biodiversity hot-spot: open woodlands, veteran trees and mature forests succumb to forestry intensification, succession, and logging in a UNESCO Biosphere Reserve. Journal for Nature Conservation 22 (1): 35-41. - doi: 10.1016/j.jnc.20 13.08.002

Nafziger S (2012). Serfdom, emancipation, and off-farm labour mobility in Tsarist Russia. Economic History of Developing Regions 27 (1): 137. - doi: 10.1080/20780389.2012.682377

Neophytou C, Aravanopoulos FA, Fink S, Dounavi A (2010). Detecting interspecific and geographic differentiation patterns in two interfertile oak species (Quercus petraea (Matt.) Liebl. and Q. robur L.) using small sets of microsatellite markers. Forest Ecology and Management 259(10): 2026-2035. - doi: 10.1016/j.foreco.2010. 
02.013

Nikodemus O, Klavinš M, Krišjane Z, Zelčs V (2018). Latvija. Zeme, daba, tauta, valsts [Latvia. Land, nature, people, state]. Latvijas Universitates Akademiskais apgads, Riga, Latvia, pp. 752. [in Latvian]

Nutt N, Nurme S, Hiob M, Salmistu S, Kotval Z (2013). Restoring Manor Parks: exploring and specifying original design and character through the study of dendrologous plants in Estonian historical Manor Parks. Baltic Forestry 19 (2): 280-288. [online] URL: http://www.re searchgate.net/publication/292395440

Potapova V (1977). Feodalo lauksaimniecibas zemju izvietojuma galvenie fiziogeografiskie faktori un to sakars ar musdienu ainavu [Main factors for location of feudal agricultural lands and their relation to present landscape]. In: "Latvijas PSR geografiskie kompleksi un cilveks" [Geographical complexes and people of Latvian SSR] (Ramans K ed). P. Stučkas Latvijas Valsts Universitate, Riga, Latvia, pp. 120. [in Latvian]

R Core Team (2018). R - language and environment for statistical computing. $\mathrm{R}$ foundation for Statistical Computing, Vienna, Austria. [online] URL: http://www.r-project.org/

Ramans K (1994). Ainavu rajonešana [Landscape zoning]. In: "Latvijas Daba 1" [Nature of Latvia Vol. 1] (Kavacs G ed). Latvijas enciklopedija, Riga, Latvia, pp. 186-188. [in Latvian]

Sauliene I, Sukiene L, Zaleskiene E, Saulys A, Aukselis K (2018). Assessment of former manors as rural landscape elements: case study of Northern Lithuania. Notulae Botanicae Horti Agrobotanici Cluj-Napoca 46 (2): 670-678. - doi: 10.158 35/nbha46211174

Schubert R, Vent W (1990). Rothmaler: Exkursionsflora von Deutschland. Gefäßpflanzen: Kritischer Band [Rothmaler: excursion flora of Germany. Vascular plants: critical volume]. Spektrum Akademischer Verlag, Berlin, Germany, pp. 811. [in German]

Sjörs H (1963). Amphi-Atlandic zonation, nemoral to Arctic. In: Proceedings of the Symposium "North Atlantic Biota and their History" (Löve A, Löve D eds). University of Iceland, Reijkijavik (Iceland) 1962. Pergamon Press, Oxford, UK, pp. 109-125.

State Forest Service (2017). Forest statistics 2016. Riga, Latvia. [online] URL: http://www. vmd.gov.lv/valsts-meza-dienests/statiskas-lapa s/publikacijas-un-statistika/meza-statistikas-cd? nid=1809\#jump

Stivrins N, Kalnina L, Veski S, Zeimule S (2014). Local and regional Holocene vegetation dynamics at two sites in eastern Latvia. Boreal Environment Research 19 (5): 310-323. [online] URL: http://helda.helsinki.fi/bitstream/handle/ 10138/228603/ber19-4-310.pdf?sequence $=1$

Strods H (1999). Latvijas mežu politika un likumdošana (XI gs. - 1940.g.) [Latvian forest policy and normative regulation (XI century - 1940)]. In: "Latvijas Meža Vesture Lidz 1940. Gadam" [The History of Forests in Latvia until 1940] (Strods H ed). WWF Latvia, Riga, Latvia, pp. 12-
107. [in Latvian]

Svabe A (1958). Latvijas vesture 1800-1914 [History of Latvia 1800-1914]. Daugava, Riga, Latvia, pp. 752. [in Latvian]

Terauds A, Brumelis G, Nikodemus O (2011). Seventy-year changes in tree species composition and tree ages in state-owned forests in Latvia. Scandinavian Journal of Forest Research 26 (5): 446-456. - doi: 10.1080/02827581.2011.586647 Vasilevskis A (2007). Latvijas valsts mežu apsaimniekošana 1918-1940 [The management of state forest in Latvia from 1918 till 1940]. Nacionalais Apgads, Riga, Latvia, pp. 430. [in Latvian]

Wulf M, Sommer M, Schmidt R (2010). Forest cover changes in the Prignitz region (NE Germany) between 1790 and 1960 in relation to soils and other driving forces. Landscape Ecology 25 (2): 299-313. - doi: 10.1007/s10980-0099411-3

Zelčs V, Saks T, Nartišs M, Markots A (2011). Chapter 18: Pleistocene glaciations in Latvia. Developments in Quaternary Sciences 15: 221229. - doi: 10.1016/B978-0-444-53447-7.00018-0 Zunde M (1999). Mežainuma un koku sugu sastava parmainu dinamika un to galvenie ietekmejošie faktori Latvijas teritorija. In: “Latvijas Meža Vesture Lidz 1940. Gadam" [The History of Forests in Latvia until 1940] (Strods H ed). WWF Latvia, Riga, Latvia, pp. 111-206. [in Latvian]. 